\title{
Inhibition of inflammatory cell infiltration by antagonistic peptides that specifically bind to CCR5 via regulation of the NF-kappa B signaling pathway in rats with colitis
}

\section{Type}

Research paper

\section{Keywords}

inflammatory bowel disease, $\mathrm{CC}$ chemokine receptor 5 , antagonistic peptides

\begin{abstract}
Introduction

CC chemokine receptor 5 (CCR5) and the NF-KB signaling pathway play important roles in the pathophysiology of inflammatory bowel disease (IBD). Previously, we synthesized two peptides (GH and $\mathrm{HY}$ peptides) that specifically bind to the first and the second extracellular loops (ECL1 and ECL2, respectively) of CCR5 and preliminarily found an inhibitory effect of these peptides on colitis. However, the specific mechanism by which these two peptides regulate trinitrobenzene sulfonic acid (TNBS)-induced colitis in rats remains unclear.
\end{abstract}

\section{Material and methods}

Experimental colitis was induced by 5\% TNBS. CCR5 antagonist peptides were administered intravenously once a day for a week. Histological evaluation, real-time PCR, western blotting and correlation analysis were performed to examine the effects of the CCR5 binding peptides on the infiltration of inflammatory cells and the NF-kB signaling pathway.

\section{Results}

$\mathrm{GH}$ and $\mathrm{HY}$ peptides ameliorated mucosal damage and reduced the infiltration of neutrophils, lymphocytes and macrophages in experimental colitis $(P<0.05)$. The expression of NF-KB-related genes, including $\mathrm{p} 105, \mathrm{p} 100$, IKK and TNF- $\alpha$, was reduced after $\mathrm{GH}$ and HY peptide administration $(P<0.01)$, and the protein level of TNF- $\alpha$ and the phosphorylation of IKK, IKB $\alpha$ and p65 were also suppressed. Furthermore, CCR5 antagonist peptides inhibited nuclear translocation of p65. Spearman correlation analysis showed that the infiltration of inflammatory cells was significantly correlated with the NF-KB pathway.

\section{Conclusions}

Antagonistic peptides that specifically bind to ECL1 and ECL2 of CCR5 inhibit the infiltration of neutrophils, lymphocytes and macrophages in the colonic mucosa of SD rats with TNBS-induced colitis via regulation of the NF-KB signaling pathway. 


\section{Inhibition of inflammatory cell infiltration by antagonistic peptides that specifically bind to CCR5 via regulation of the NF-kappa B signaling pathway in rats with colitis}

Yang-Da Song ${ }^{1,2}$, Yi-Hang Song ${ }^{1,2}$, Si-Xue Liu ${ }^{1,2}$, Hua-Rong Huang ${ }^{2,3}$, Ying-Qiang Zhong ${ }^{1,2}$

${ }^{1}$ Department of Gastroenterology, Sun Yat-Sen memorial Hospital, Sun Yat-Sen University, Guangzhou, China

${ }^{2}$ Key Laboratory of Malignant Tumor Gene Regulation and Target Therapy of Guangdong Higher Education Institutes of Sun Yat-Sen University, Guangzhou, China ${ }^{3}$ Department of Pediatrics, Sun Yat-Sen memorial Hospital, Sun Yat-Sen University, Guangzhou, China

Correspondence to: Ying-Qiang Zhong, Department of Gastroenterology, Sun Yat-sen Memorial Hospital, Sun Yat-sen University, 107 Yanjiang West Road, Guangzhou, 510120, Guangdong Province, China.

Phone/fax: +86 2081332598 ;

E-mail: yingqiangzhong@ 126.com 


\begin{abstract}
Introduction

$\mathrm{CC}$ chemokine receptor $5(\mathrm{CCR} 5)$ and the NF- $\kappa \mathrm{B}$ signaling pathway play important roles in the pathophysiology of inflammatory bowel disease (IBD). Previously, we synthesized two peptides (GH and HY peptides) that specifically bind to the first and the second extracellular loops (ECL1 and ECL2, respectively) of CCR5 and preliminarily found an inhibitory effect of these peptides on colitis. However, the specific mechanism by which these two peptides regulate trinitrobenzene sulfonic acid (TNBS)-induced colitis in rats remains unclear.
\end{abstract}

\title{
AIM
}

To further investigate the effect and mechanism of CCR5 binding peptides in rat colitis.

\section{METHODS}

Experimental colitis was induced by 5\% TNBS. CCR5 antagonist peptides were administered intravenously once a day for a week. Histological evaluation, real-time PCR, western blotting and correlation analysis were performed to examine the effects of the CCR5 binding peptides on the infiltration of inflammatory cells and the NF- $\mathrm{kB}$ signaling pathway.

\section{RESULTS}

Administration of GH and HY peptides ameliorated mucosal damage and reduced the infiltration of neutrophils, lymphocytes and macrophages in experimental colitis $(P<$ 
0.05). The expression of NF- $\kappa B-r e l a t e d$ genes, including p105, p100, IKK and TNF- $\alpha$, was reduced after GH and HY peptide administration $(P<0.01)$, and the protein level of TNF- $\alpha$ and the phosphorylation of IKK, I $\mathrm{BB} \alpha$ and p65 were also suppressed. Furthermore, the CCR5 antagonist peptides inhibited nuclear translocation of p65. Spearman correlation analysis showed that the infiltration of inflammatory cells was significantly correlated with the NF- $\kappa \mathrm{B}$ pathway.

\section{CONCLUSION}

Antagonistic peptides that specifically bind to ECL1 and ECL2 of CCR5 inhibit the infiltration of neutrophils, lymphocytes and macrophages in the colonic mucosa of SD rats with TNBS-induced colitis via regulation of the NF- $\mathrm{BB}$ signaling pathway.

Key words: inflammatory bowel disease, CC chemokine receptor 5, antagonistic peptides; NF- $\kappa \mathrm{B}$

\section{Introduction}

Inflammatory bowel disease (IBD) is a group of chronic nonspecific intestinal inflammatory diseases with unknown etiology, including Crohn's disease, ulcerative colitis and indeterminate colitis [1]. Its prominent pathophysiological features are characterized by infiltration of multiple inflammatory cells in the intestine, activation of various inflammatory signaling pathways and the release of multiple inflammatory 
cytokines, resulting in persistent inflammation and damage to the intestinal mucosa [2].

CC chemokine receptor 5 (CCR5) is a chemokine receptor that belongs to the family of $\mathrm{G}$ protein coupled receptors (GPCRs). CCR5 regulates recruitment and activation of several kinds of inflammatory cells [3]. CCR5 is also involved in the pathogenesis of various immune diseases, such as asthma [4], autoimmune myocarditis [5], rheumatoid arthritis [6] and IBD [7]. Structurally, CCR5 contains an extracellular N-terminal, three extracellular loops (ECL1, ECL2 and ECL3), seven-transmembrane $\alpha$-helices, three intracellular loops and an intracellular C-terminal [8]. After binding to its ligands, the intracellular C-terminal, which is coupled with the G protein, is phosphorylated and involved in various signaling pathways, including the MAPK, JAK-STAT and NF- $\mathrm{BB}$ signal pathways $[9,10,11]$.

As a ubiquitously expressed transcription factor, $\mathrm{NF}-\kappa \mathrm{B}$ has been shown to play a pivotal role in inflammation, immune regulation and cell apoptosis [12]. The NF- $\kappa$ B family is composed of five proteins, including p65/RelA, c-Rel, RelB, NF- $\kappa B 1$ (p105/p50) and NF-кB2 (p100/p52) in mammals. Among them, p105 and p100 are the precursor proteins of p50 and p52, respectively. In unstimulated conditions, NF- $\kappa$ B is localized to the cytoplasm where it is tightly bound to the inhibitory protein IкB (inhibitor kappa B) [13]. Several inflammatory stimuli (e.g., TNF- $\alpha$, LPS, IL-1 and mitogens) can activate the $\mathrm{I} \kappa \mathrm{B}$ kinase (IKK) complex. Then, the IKK complex phosphorylates IאBs, resulting in the ubiquitination and subsequent degradation of IkBa by the proteasome and the liberation and nuclear translocation of active NF- $\kappa \mathrm{B}$ dimers, 
which are able to bind to DNA and regulate the transcription of multiple genes involved in inflammation and the immune response, such as IL-1 $\beta$ and TNF- $\alpha$ [14].

As one of the key regulators of the immune response, NF- $\mathrm{BB}$ is associated with the pathophysiology of IBD. Expression and activation of NF- $\mathrm{BB}$ results in the dominance of proinflammatory cytokines such as TNF- $\alpha$, IL- $1 \beta$ and IFN- $\gamma$, which cause colonic mucosal inflammation and damage [15]. On the other hand, many treatments of IBD have been shown to inhibit the NF-kB signaling pathway $[16,17,18]$. Therefore, blocking the activation of $\mathrm{NF}-\kappa \mathrm{B}$ might be an effective target of therapeutic interventions in IBD.

Our previous study showed that CCR5 is closely related to the pathogenesis of IBD and is highly expressed in the colonic mucosa of patients with IBD [19]. Using phage display technology, we successfully screened two bioactive peptides that specifically bind to the first and the second extracellular loops (ECL1 and ECL2) of CCR5 and preliminarily found an inhibitory effect of these peptides on colitis. [20]. In addition, in another related study, we found that the CCR5 antagonist peptides reduce airway inflammation by suppressing the IL-23/Th17 signaling pathway [21]. Therefore, CCR5 is closely related to a variety of autoimmune diseases, including IBD. And the purpose of this study was to examine the effects of the two peptides on inflammatory cell infiltration and the NF- $\mathrm{BB}$ signaling pathway in the colonic mucosa of TNBS-induced experimental colitis rats. 


\section{Materials and methods}

\section{Reagents}

A 5\% solution of 2,4,6-trinitrobenzene sulfonic acid (TNBS) was purchased from Sigma-Aldrich (St. Louis, MO, USA). The rabbit antibodies, including anti-IKK $\beta$, anti-phospho-IKK $\alpha / \beta$ (Ser176/180), anti-p65, anti-phospho-p65 (Ser536), anti-IкB $\alpha$ and anti-phospho-IкB $\alpha$ (Ser32), were purchased from Cell Signaling Technology (Danvers, MA, USA). The rabbit antibodies, including anti-TNF- $\alpha$, anti- $\beta$-actin, and anti-TBP, were purchased from Novus Biologicals, LLC (Littleton, CO, USA). Two peptides that specifically bind to ECL1 and ECL2 of CCR5 were synthesized by GL Biochem Ltd. (Shanghai, China). The sequences of the two peptides were GHWKVWL $(\mathrm{GH})$ and HYIDFRW (HY). More details of the two peptides including (HPLC and Mass spectrum analysis report) were listed in the supplemental materials (Table S1).

\section{Animals and Groupings}

The study was approved by the institutional animal care and use committee and the experimental animal ethics committee of Sun Yat-sen University. The license number is IACUC-DB-16-0313. Forty female Sprague-Dawley (SD) rats weighing 180-220 g were purchased from the experimental animal center of Sun Yat-sen University (Guangzhou, China). After feeding for 1 week, the forty rats were randomly divided into four groups: (1) Normal control group (N group), (2) Model colitis group (M group); (3) GH peptide treatment group (GH group); and (4) HY peptide treatment 
group (HY group). The rats were fed laboratory chow and tap water in standard cages in a specific pathogen-free (SPF) environment where the temperature was $19-22^{\circ} \mathrm{C}$ and the humidity was $50-60 \%$ with a 12 h day and night cycle. Before induction of experimental colitis, the rats were fasted for $24 \mathrm{~h}$ and fed with a $5 \%$ glucose solution during that period.

\section{Establishment of Experimental Colitis}

The procedure of inducing colitis was mainly based on Morris et al. [22]. After anesthesia by intraperitoneal injection of $0.3 \%$ pentobarbital sodium $(0.6 \mathrm{mg} / \mathrm{kg})$, the rats were given an enema with $100 \mathrm{mg} / \mathrm{kg}$ TNBS dissolved in $0.3 \mathrm{ml}$ of $50 \%$ ethanol via a 16\# animal feeding needle (the tip was $8 \mathrm{~cm}$ proximal to the anus, approximately to the rat's splenic flexure). Then, the rats were kept in a head-down position for 5 minutes to prevent the TNBS from leaking out. None of the rats exhibited signs of peritonitis after the administration of $0.3 \%$ pentobarbital sodium.

\section{Drug Administration}

On the third day after TNBS administration, rats in the treatment groups were treated with GH peptide $(35 \mathrm{mg} / \mathrm{kg})$ and HY peptide $(25 \mathrm{mg} / \mathrm{kg})$ via tail vein injection, while rats in the normal and model groups were injected with sterile saline $(0.9 \% \mathrm{NaCl})$. All injections were given once a day and lasted for seven days. The concentrations of peptides were determined based on our previous study [23], and the results were listed 
in the supplementary materials (Table S2). Twelve days after the TNBS enema, the rats were euthanized, and colon tissue samples were collected for further histological and molecular biology analysis. Humane endpoints were evaluated by a clinical scoring system (in the supplementary materials--Table S3) and rats were anesthetized and euthanized by decapitation when termination criteria were fulfilled or at the end of the experiment.

\section{Histological Evaluation}

The colon samples were fixed in $4 \%$ paraformaldehyde overnight and embedded in paraffin. Then, they were sectioned at a thickness of $5 \mu \mathrm{m}$ and stained with hematoxylin and eosin. Histological assessments including ulceration, inflammation and types of inflammatory cells were performed under a microscope. Inflammatory cells, including neutrophils, eosinophils, lymphocytes and macrophages, were counted in ten randomly selected high-power fields (HPFs) at 400× magnification.

\section{Proteins Extraction and Western blotting}

Total protein lysates were collected by RIPA lysis buffer. The nuclear extracts were prepared by using a nuclear and cytoplasmic protein extraction kit (Beyotime Biotechnology Ltd; Shanghai, China). Equal amounts of samples (as determined by BCA protein assay) were loaded onto SDS-PAGE gels $(20 \mu \mathrm{l})$ and transferred to nitrocellulose membranes. After blocking in 5\% nonfat milk, the membranes were 
incubated with the relevant primary antibodies at $4{ }^{\circ} \mathrm{C}$ overnight. Then, the membranes were probed with HRP-linked secondary antibodies at room temperature for $1 \mathrm{hr}$. Finally, the proteins were visualized by the ECL method (Millipore; Burlington, MA, USA). To control for loading, $\beta$-actin and TBP served as the housekeeping proteins for the total and nuclear proteins, respectively.

\section{Real-time PCR}

Total RNA was isolated by RNAiso Plus (Takara Bio Inc, Dalian, China). Real-time PCR was performed by using SYBR Green PCR master mix reagent kits after reverse transcription to cDNA, and $\beta$-actin was used as the housekeeping gene. The real-time PCR cycling parameters were $95^{\circ} \mathrm{C}$ for $30 \mathrm{~s}$, followed by 40 cycles of $95^{\circ} \mathrm{C}$ for $5 \mathrm{~s}$ and $60^{\circ} \mathrm{C}$ for $30 \mathrm{~s}$. The primer sequences are listed in Table I. All primers were synthesized by Sangon Biotech Ltd. (Shanghai, China).

\section{Statistical Analysis}

Normality was assessed by the Kolmogorov-Smirnov test. For normal distribution, data are shown as the means \pm SD and were analyzed by one-way ANOVA and the LSD multiple comparison test. For abnormal distribution, data are shown as medians [interquartile ranges] and were analyzed by the Kruskal-Wallis $H$ test and Nemenyi multiple comparison test. All statistical analyses were performed using SPSS software (version 22.0). Correlation analysis was assessed by the Spearman correlation test. For 
all tests, $P<0.05$ was considered statistically significant.

\section{Results}

Effects of GH and HY peptides on the histological damage and infiltration of inflammatory cells

Compared with the histological features in the normal control, the histological features of the colonic mucosa in the model group manifested as mucosal ulceration, epithelial erosion, crypt damage and distortion and infiltration of large numbers of neutrophils and lymphocytes and some macrophages and eosinophils (Figure 1 A-B). However, administration of GH or HY peptide resulted in a decrease in the extent of inflammation (mainly located in the submucosa) (Figure $1 \mathrm{C}-\mathrm{D}$ ) and infiltration of neutrophils, lymphocytes and macrophages compared with those of the model group. There was no significant difference in the number of inflammatory cells and the morphology of the colonic mucosa between the two peptide groups, and there was no difference in the number of eosinophils in the GH and HY treatment groups compared with that of the model group. The inflammatory cell counts are listed in Table II.

Effects of GH and HY peptides on the gene expression of p100, p105, p65,

\section{IKK and TNF- $\alpha$}

The expression levels of NF-кB-related genes, including p105, p100, p65, IKK and TNF- $\alpha$, were tested by real-time PCR (Figure 2). The mRNA levels of p105, p100, IKK 
and TNF- $\alpha$ in the model group increased by approximately 16-, 3.8-, 8- and 6.8-fold, respectively, $(P<0.01)$ compared with those of the normal control. In contrast, the mRNA levels of p100, p105, IKK and TNF- $\alpha$ in the GH or HY peptide groups decreased compared with those of the model control. There was no difference in the expression of p65 mRNA among the four groups $(P>0.05)$.

Effects of GH and HY peptides on the protein expression of the NF-кB signaling pathway and the phosphorylation of IKK, IKB $\alpha$ and p65

The expression of NF-kB-related proteins was tested by western blotting. The results showed that the protein levels of p-IKK (phospho-IKK), p-p65 (phospho-p65), $\mathrm{p}-\mathrm{I} \kappa \mathrm{B} \alpha$ (phospho-I $\kappa \mathrm{B} \alpha$ ) and TNF- $\alpha$ in the model rats were significantly increased by approximately 1.4-, 1.9-, 1.7- and 1.6-fold, respectively, and the protein level of I $\mathrm{B} \alpha$ was significantly decreased compared with those of the normal group $(P<0.05)$ (Figure 3 , indicating a significantly activated NF- $\mathrm{BB}$ signaling pathway and degradation of $\mathrm{I} \kappa \mathrm{B} \alpha$. In contrast, the GH or HY peptide resulted in decreased levels of p-IKK, p-p65, $\mathrm{p}-\mathrm{I} \kappa \mathrm{B} \alpha$ and TNF- $\alpha$ compared with those of the model group. Compared with the levels in the normal group, there was no difference in the protein levels of $\mathrm{I} \kappa \mathrm{B} \alpha$ and $\mathrm{p}-\mathrm{I} \kappa \mathrm{B} \alpha$ in the CCR5 peptide treatment groups. Furthermore, no differences were observed in the protein levels of IKK and p65 among the four groups.

Effect of GH and HY peptides on the nuclear translocation of p65 
To further demonstrate whether CCR5 antagonist peptides downregulated NF-кB activity in experimental colitis, we performed western blotting to examine p65 in nuclear extracts. The results showed that in the colitis rats, nuclear p65 was significantly increased compared with that of the normal control. In contrast, GH or HY peptides reduced p65 in the nucleus compared with that of the model group $(P<0.05)$. The results are shown in Figure 4.

\section{Correlation analysis between inflammatory cell infiltration and the NF-кB}

\section{pathway}

Tables III, IV and V show the results of the Spearman correlation analysis of inflammatory cell infiltration and NF- $\kappa \mathrm{B}$ pathway expression, while the NF- $\kappa \mathrm{B}$ pathway was activated and inhibited, respectively. Parts of the scatter plot results are shown in the supplementary materials (Figure S1).

First, the comparison between the normal group and the model group was performed (Table III). The results showed that except for the protein p65, the infiltration of inflammatory cells was significantly correlated with the NF- $\mathrm{BB}$ pathway. Among

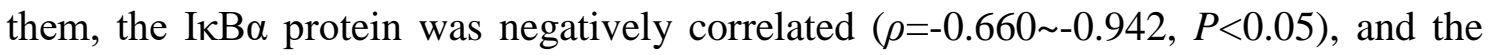
others were positively correlated $(\rho=0.692 \sim 0.988, P<0.05)$.

After application of the GH peptide (Table IV), the infiltration of neutrophils, lymphocytes and macrophages was not related to the protein IKK but was related to p-IKK $(\rho=0.918, \rho=0.821$ and $\rho=0.780$, respectively, $P<0.05$ ). There was no significant 
difference in the correlation between the protein p65 and lymphocyte, eosinophil and macrophage infiltration. Except for the above indicators, the infiltration of inflammatory

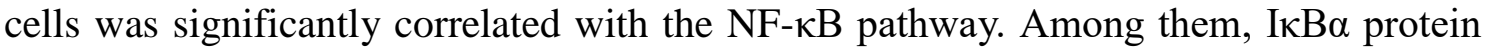
was negatively correlated $(\rho=-0.660 \sim-0.854, P<0.05)$, and the others were positively correlated $(\rho=0.590 \sim 0.964, P<0.05)$.

After applying the HY peptide (Table V), the infiltration of neutrophils and lymphocytes was not related to the protein IKK but was related to $\mathrm{p}$-IKK ( $\rho=0.894$ and $\rho=0.831$, respectively, $P<0.05)$. There was no significant difference in the correlation between the protein p65 and neutrophil, lymphocyte and macrophage infiltration. Eosinophil infiltration was not significantly correlated with the proteins $\mathrm{p}-\mathrm{I} \kappa \mathrm{B} \alpha$ and TNF- $\alpha$ and TNF- $\alpha$ mRNA. Except for the above indicators, the infiltration of inflammatory cells was significantly correlated with the NF- $\mathrm{B}$ pathway. Among them, $\mathrm{I} \kappa \mathrm{B} \alpha$ protein was negatively correlated $(\rho=-0.660 \sim-0.944, P<0.05)$, and the others were positively correlated $(\rho=0.496 \sim 0.968, P<0.05)$.

\section{Discussion}

The present study demonstrates that the two CCR5 antagonist peptides can inhibit the infiltration of inflammatory cells and the NF-kB pathway in experimental colitis. Previous studies have shown a close relationship between CCR5 and the pathogenesis of IBD [24, 25, 26]. Kucuk $C$ et al. [27] found that Met-RANTES, a modified chemokine that internalizes and downregulates CCR5, attenuates colitis and decreases 
bacterial translocation in experimental colitis. Another study showed that TAK-779, which is a nonpeptide small-molecule antagonist of CCR5, ameliorates dextran sodium sulfate (DSS)-mediated colitis and inhibits the infiltration of monocytes/macrophages and the production of proinflammatory cytokines such as IL-1 $\beta$ and IL-6 [28]. Furthermore, similar results in human IBD demonstrated that CCR5 is highly expressed in the inflamed mucosa and is associated with the disease activity of IBD [19, 29]. These studies established that CCR5 plays an important role in the development of IBD and that CCR5 antagonists might be a novel therapy for IBD.

To date, several CCR5 antagonists have been developed, such as modified chemokines (Met-RANTES) [27], small-molecule agents (TAK-779), monoclonal antibodies (2D7) [30] and short-peptide antagonists. Among them, short-peptide antagonists specifically bind to the extracellular part of CCR5 and have a high affinity and safety. In addition, the low cost of production was another advantage of short-peptide antagonists. Therefore, we screened and synthesized two CCR5 antagonist peptides by the phage-displayed peptide library [20] and evaluated the effects of these peptides on TNBS-induced colitis, which is a classic animal model of IBD [31].

Histopathologic assessment revealed that injection of GH or HY peptide reduced the degree and range of inflammation and alleviated the infiltration of neutrophils, lymphocytes and macrophages. Previous studies showed that CCR5 is widely expressed on the cell surface of dendritic cells, monocytes/macrophages, and neutrophils, as well as effector and regulatory T-cells $[32,33]$. Our results indicated that since CCR5 is 
associated with the migration of neutrophils, lymphocytes and macrophages to the inflamed lesion, CCR5 antagonistic peptides might attenuate histological damage and infiltration of neutrophils, lymphocytes and macrophages in experimental colitis by blocking the binding of CCR5 with its ligand. In addition, eosinophils in the model group were higher than those in the normal control group, which was consistent with previous studies $[19,31]$. However, the infiltration of eosinophils in the two CCR5 antagonistic peptide-treated groups was not significantly different from that in the model group, which might be due to the low expression of CCR5 on eosinophils.

Previous studies have emphasized the importance of NF- $\kappa \mathrm{B}$ pathway in IBD and TNBS-induced colitis $[34,35,36]$. Our study found that the expression of p105, p100, IKK and TNF- $\alpha$ increased in TNBS-induced colitis but decreased after treatment with $\mathrm{GH}$ or $\mathrm{HY}$ peptides, indicating that $\mathrm{GH}$ and $\mathrm{HY}$ peptides inhibit the transcription potential of NF- $\kappa$ B-related genes. Western blot results showed that the expression levels of p-IKK, p-p65, p-IкB $\alpha$ and TNF- $\alpha$ increased in the model rats compared with those of the normal control. After treatment with GH or HY peptide, these increased proteins were reduced significantly. Since $\mathrm{I} \kappa \mathrm{B} \alpha$ is a key molecular target involved in the

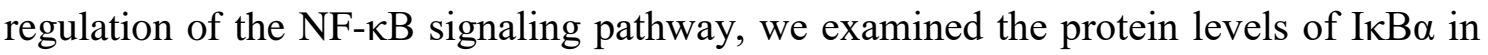
the four groups and observed high levels of $I \kappa \mathrm{B} \alpha$ in the normal control, while in the colitis model, the degradation of $\mathrm{I} \kappa \mathrm{B} \alpha$ was up to approximately $42 \%$ (by measuring the gray value) (Figure 3). In contrast, the levels of $\mathrm{I} \kappa \mathrm{B} \alpha$ increased further in rats administered GH or HY peptide. Because the application of GH and HY peptides also 
suppressed the phosphorylation of IKK, we suggest that the inhibitory action of GH and HY peptides on the NF- $\mathrm{KB}$ signaling pathway lies upstream of the activation of the IKK complex and phosphorylation of $\operatorname{I\kappa B} \alpha$ and p65. Moreover, TNF- $\alpha$, which is an important product and inducer of $\mathrm{NF}-\kappa \mathrm{B}$, was also inhibited by the CCR5 antagonist peptides. These results were consistent with previous PCR data on the ability of GH and HY peptides to inhibit NF- $\kappa B$-related genes.

To further verify the inhibition of NF-kB activity by GH and HY peptides, we examined the level of p65 in nuclear extracts. The reduction in p65 in the nucleus indicated that application of GH and HY peptides suppressed the nuclear translocation of $\mathrm{p} 65$, rather than changing the total amount of $\mathrm{p} 65$. This result could also explain why no differences were found in the mRNA and total protein levels of p65 among the four groups. In summary, after binding to CCR5, the two CCR5 antagonist peptides inhibit the function of CCR5 and activation of the IKK complex, reducing the phosphorylation of $\mathrm{I} \kappa \mathrm{B}$, stabilizing $\mathrm{p} 65$, and ultimately suppressing the nuclear translocation of p65.

To investigate the relationship between inflammatory cell infiltration and the NF- $\mathrm{B}$ pathway, we analyzed the relationship between inflammatory cell counts and

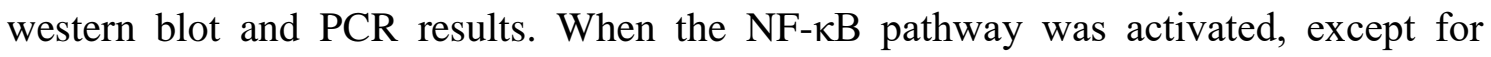
protein p65, the infiltration of inflammatory cells was correlated with the other indicators in the NF- $\mathrm{BB}$ pathway. This result suggest that the infiltration of inflammatory cells is closely related to the activation of the NF- $\mathrm{B}$ pathway, which was also consistent with other studies [37]. In addition, correlation analysis showed that the 


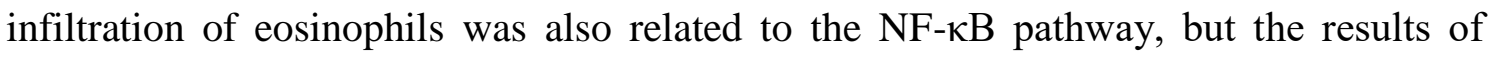
inflammatory cell counts under the microscope showed that there was no significant difference in the degree of eosinophil infiltration between the treatment and model group. This may be due to the small number of eosinophils in each group or the low expression of CCR5 in eosinophils [19].

Studies have shown that CCR5 is essential for activation of the NF- $\mathrm{B}$ pathway during viral infection [38]. In this study, we also explored the effects of the two CCR5 antagonist peptides on the NF- $\kappa \mathrm{B}$ pathway. The correlation results showed that the two peptides had different effects on inflammatory cell infiltration and the NF- $\kappa$ B pathway, but there was no significant difference between the two peptides in the previous PCR and WB analysis. This may provide ideas for further study of CCR5 antagonist peptides: the ECL1-binding peptide may focus on inhibiting the phosphorylation of IKK in neutrophils and lymphocytes, whereas the ECL2-binding peptide may affect the phosphorylation of IKK in neutrophils. In general, inflammatory cell infiltration was associated with most NF- $\mathrm{B}$ pathway markers after intervention with the CCR5 antagonist peptides. This suggests that CCR5 antagonist peptides are likely to inhibit inflammatory cell infiltration by inhibiting the expression and activation of the NF- $\mathrm{kB}$ pathway, thereby reducing histological damage due to colitis in rats. The overall effect of CCR5 binding peptides on the NF- $\mathrm{BB}$ pathway is demonstrated in Figure 5.

It was noteworthy that there were no significant differences in histology or protein or gene levels between the GH group and HY group. Different studies on CCR5 
functional binding sites had various opinions. Early studies on CCR5 and HIV-1 in CD4+ $\mathrm{T}$ cells suggested that the N-terminus and the second ECL of CCR5 played critical roles in HIV-1 coreceptor function [39]. In 2013, Einat Schnur et al [40] mapped and examined the interactions and affinity of the extracellular domain of CCR5 with its chemokine RANTES by nuclear magnetic resonance (NMR). In terms of the single structure, the N-terminal and ECL2 were found to have higher affinities in binding to RANTES. However, the binding affinity of ECL1-ECL2 with RANTES was obviously stronger than that of ECL2 alone. This was due to the conformational stabilization of ECL2 induced by ECL1. In other words, blocking either ECL1 or ECL2 alone would lead to a reduction in the binding affinity of CCR5 to its ligands. Therefore, blocking both ECL1 and ECL2 at the same time may more strongly inhibit CCR5.

In conclusion, our study indicates that CCR5 antagonist peptides that specifically bind to ECL1 and ECL2 of CCR5 inhibit the infiltration of neutrophils, lymphocytes and macrophages in the colonic mucosa of rats with colitis by inhibiting the activation of the NF- $\kappa \mathrm{B}$ pathway. Thus, the application of CCR5 antagonist peptides might be a potential therapeutic approach for treating IBD. Further study on the pharmacokinetics and the synergistic effects of the two peptides will be beneficial for future clinical applications.

\section{Funding}

This study was supported by the National Natural Science Foundation of China (No: 
81370499), Natural Science Foundation of Guangdong, China (No: 2014A030313020), and Natural Science Foundation of Guangzhou, Guangdong, China (No: 20180301004).

\section{Competing interests}

The authors declare no conflict of interest.

\section{References}

1.Kawalec P: Indirect costs of inflammatory bowel diseases: Crohn's disease and ulcerative colitis. A systematic review. ARCH MED SCI 2016; 12: 295-302.

2.Koenecke C, Forster R: CCR9 and inflammatory bowel disease. Expert Opin Ther Targets 2009; 13: 297-306.

3.Jones KL, Maguire JJ, Davenport AP: Chemokine receptor CCR5: from AIDS to atherosclerosis. Br J Pharmacol 2011; 162: 1453-1469.

4.Hogaboam CM, Carpenter KJ, Schuh JM, Proudfoot AA, Bridger G, Buckland KF: The therapeutic potential in targeting CCR5 and CXCR4 receptors in infectious and allergic pulmonary disease. Pharmacol Ther 2005; 107: 314-328.

5.Machado FS, Koyama NS, Carregaro V, Ferreira BR, Milanezi CM, Teixeira MM, Rossi MA, Silva JS: CCR5 plays a critical role in the development of myocarditis and host protection in mice infected with Trypanosoma cruzi. J INFECT DIS 2005; 191: 627-636.

6.Vierboom MP, Zavodny PJ, Chou CC, Tagat JR, Pugliese-Sivo C, Strizki J, 
Steensma RW, McCombie SW, Celebi-Paul L, et al.: Inhibition of the development of collagen-induced arthritis in rhesus monkeys by a small molecular weight antagonist of CCR5. Arthritis Rheum 2005; 52: 627-636.

7.Moldoveanu AC, Diculescu M, Braticevici CF: Cytokines in inflammatory bowel disease. Rom J Intern Med 2015; 53: 118-127.

8.Flegler AJ, Cianci GC, Hope TJ: CCR5 conformations are dynamic and modulated by localization, trafficking and G protein association. PLOS ONE 2014; 9: e89056.

9.Kim HK, Park HR, Sul KH, Chung HY, Chung J: Induction of RANTES and CCR5 through NF-kappaB activation via MAPK pathway in aged rat gingival tissues. BIOTECHNOL LETT 2006; 28: 17-23.

10.Mueller A, Strange PG: CCL3, acting via the chemokine receptor CCR5, leads to independent activation of Janus kinase 2 (JAK2) and Gi proteins. FEBS LETT 2004; 570: $126-132$.

11.Lee NJ, Choi DY, Song JK, Jung YY, Kim DH, Kim TM, Kim DJ, Kwon SM, Kim $\mathrm{KB}$, et al.: Deficiency of C-C chemokine receptor 5 suppresses tumor development via inactivation of NF-kappaB and inhibition of monocyte chemoattractant protein-1 in urethane-induced lung tumor model. CARCINOGENESIS 2012; 33: 2520-2528.

12.Sun SC, Chang JH, Jin J: Regulation of nuclear factor-kappaB in autoimmunity. TRENDS IMMUNOL 2013; 34: 282-289.

13.Chiba T, Inoko H, Kimura M, Sato T: Role of nuclear IkappaBs in inflammation regulation. Biomol Concepts 2013; 4: 187-196. 
14.Panday A, Inda ME, Bagam P, Sahoo MK, Osorio D, Batra S: Transcription Factor NF-kappaB: An Update on Intervention Strategies. Arch Immunol Ther Exp (Warsz) 2016; 64: 463-483.

15.Atreya I, Atreya R, Neurath MF: NF-kappaB in inflammatory bowel disease. J INTERN MED 2008; 263: 591-596.

16.Kim W, Nam J, Lee S, Jeong S, Jung Y: 5-Aminosalicylic Acid Azo-Linked to Procainamide Acts as an Anticolitic Mutual Prodrug via Additive Inhibition of Nuclear Factor kappaB. Mol Pharm 2016; 13: 2126-2135.

17.Urbano PC, Soccol VT, Azevedo VF: Apoptosis and the FLIP and NF-kappa B proteins as pharmacodynamic criteria for biosimilar TNF-alpha antagonists. Biologics 2014; 8: 211-220.

18.Quaglio AE, Castilho AC, Di Stasi LC: Experimental evidence of heparanase, Hsp70 and NF-kappaB gene expression on the response of anti-inflammatory drugs in TNBS-induced colonic inflammation. LIFE SCI 2015; 141: 179-187.

19.Ye X, Liu S, Hu M, Song Y, Huang H, Zhong Y: CCR5 expression in inflammatory bowel disease and its correlation with inflammatory cells and beta-arrestin2 expression. Scand J Gastroenterol 2017; 52: 551-557.

20.Liu S, Hu M, Ye X, Huang H, Zhong Y: Panning and identification of antagonistic active peptides specifically binding to the first and second extracellular membrane loops of rat CCR5 by technique of phage display peptide library. Chinese Journal of Pathophysiology 2015; 7: 1225-1230. 
21.Zhang Y, Liang R, Xie A, Shi W, Huang H, Zhong Y, Fröde TS: Antagonistic Peptides That Specifically Bind to the First and Second Extracellular Loops of CCR5 and Anti-IL-23p19 Antibody Reduce Airway Inflammation by Suppressing the IL-23/Th17 Signaling Pathway. MEDIAT INFLAMM 2020; 2020: 1719467.

22.Morris GP, Beck PL, Herridge MS, Depew WT, Szewczuk MR, Wallace JL: Hapten-Induced Model of Chronic Inflammation and Ulceration in the Rat Colon. GASTROENTEROLOGY 1989; 96: 795-803.

23.Hu M, Song Y, Liu S, Huang H, Zhong Y: Effects of antagonistic peptides binding specifically with first and second extracellular loops of CCR5 on colitis rats induced by TNBS. Chinese Journal of Pathophysiology 2017; 5: 902-907.

24.Thomas S, Baumgart DC: Targeting leukocyte migration and adhesion in Crohn's disease and ulcerative colitis. INFLAMMOPHARMACOLOGY 2012; 20: 1-18.

25.Gorgi Y, Ben AW, Sfar I, Aounallah-Skhiri H, Mouelhi L, Jendoubi-Ayed S, Makhlouf M, Ben RT, Matri S, et al.: Association of chemokine and chemokine receptor polymorphisms with activity degree of IBD in Tunisian patients. Arch Inst Pasteur Tunis 2011; 88: 47-58.

26.Ajuebor MN, Hogaboam CM, Kunkel SL, Proudfoot AE, Wallace JL: The chemokine RANTES is a crucial mediator of the progression from acute to chronic colitis in the rat. J IMMUNOL 2001; 166: 552-558.

27.Kucuk C, Sozuer E, Gursoy S, Canoz O, Artis T, Akcan A, Akyildiz H, Muhtaroglu S: Treatment with Met-RANTES decreases bacterial translocation in experimental 
colitis. AM J SURG 2006; 191: 77-83.

28.Tokuyama H, Ueha S, Kurachi M, Matsushima K, Moriyasu F, Blumberg RS, Kakimi K: The simultaneous blockade of chemokine receptors CCR2, CCR5 and CXCR3 by a non-peptide chemokine receptor antagonist protects mice from dextran sodium sulfate-mediated colitis. INT IMMUNOL 2005; 17: 1023-1034.

29.Matsuzaki K, Hokari R, Kato S, Tsuzuki Y, Tanaka H, Kurihara C, Iwai A, Kawaguchi A, Nagao S, et al.: Differential expression of CCR5 and CRTH2 on infiltrated cells in colonic mucosa of patients with ulcerative colitis. J Gastroenterol Hepatol 2003; 18: 1081-1088.

30.Aarons EJ, Beddows S, Willingham T, Wu L, Koup RA: Adaptation to blockade of human immunodeficiency virus type 1 entry imposed by the anti-CCR5 monoclonal antibody 2D7. VIROLOGY 2001; 287: 382-390.

31.Brenna O, Furnes MW, Drozdov I, van Beelen GA, Flatberg A, Sandvik AK, Zwiggelaar RT, Marvik R, Nordrum IS, et al.: Relevance of TNBS-colitis in rats: a methodological study with endoscopic, histologic and Transcriptomic characterization and correlation to IBD. PLOS ONE 2013; 8: e54543.

32.Griffith JW, Sokol CL, Luster AD: Chemokines and chemokine receptors: positioning cells for host defense and immunity. ANNU REV IMMUNOL 2014; 32: $659-702$.

33.Reichel CA, Khandoga A, Anders HJ, Schlondorff D, Luckow B, Krombach F: Chemokine receptors $\mathrm{Ccr} 1, \mathrm{Ccr} 2$, and $\mathrm{Ccr} 5$ mediate neutrophil migration to 
postischemic tissue. J Leukoc Biol 2006; 79: 114-122.

34.Lawrance IC, Wu F, Leite AZ, Willis J, West GA, Fiocchi C, Chakravarti S: A murine model of chronic inflammation-induced intestinal fibrosis down-regulated by antisense NF-kappa B. GASTROENTEROLOGY 2003; 125: 1750-1761.

35.Wei J, Feng J: Signaling pathways associated with inflammatory bowel disease. Recent Pat Inflamm Allergy Drug Discov 2010; 4: 105-117.

36.Du X, Chen W, Wang Y, Chen C, Guo L, Ju R, Li J, Zhang D, Zhu L, et al.: Therapeutic efficacy of carboxyamidotriazole on 2,4,6-trinitrobenzene sulfonic acid-induced colitis model is associated with the inhibition of NLRP3 inflammasome and NF-kappaB activation. INT IMMUNOPHARMACOL 2017; 45: 16-25.

37.Wei HY, Ma X: Tamoxifen reduces infiltration of inflammatory cells, apoptosis and inhibits IKK/NF-kB pathway after spinal cord injury in rats. NEUROL SCI 2014; 35: 1763-1768.

38.Christmann BS, Moran JM, McGraw JA, Buller RM, Corbett JA: Ccr5 regulates inflammatory gene expression in response to encephalomyocarditis virus infection. AM J PATHOL 2011; 179: 2941-2951.

39.Agrawal L, VanHorn-Ali Z, Berger EA, Alkhatib G: Specific inhibition of HIV-1 coreceptor activity by synthetic peptides corresponding to the predicted extracellular loops of CCR5. BLOOD 2004; 103: 1211-1217.

40.Schnur E, Kessler N, Zherdev Y, Noah E, Scherf T, Ding FX, Rabinovich S, Arshava B, Kurbatska V, et al.: NMR mapping of RANTES surfaces interacting with 
CCR5 using linked extracellular domains. FEBS J 2013; 280: 2068-2084. 
Table I. Primer sequences for real time PCR

\begin{tabular}{cl}
\hline Rat Gene & \multicolumn{1}{c}{$\begin{array}{c}\text { Primers }\left(5^{\prime}{ }^{\prime} 3^{\prime}\right) \\
\text { F: forward; } \text { : } \text { reverse }\end{array}$} \\
\hline$\beta$-actin & $\begin{array}{c}\text { F: GGGAAATCGTGCGTGACATT } \\
\text { R: GCGGCAGTGGCCATCTC }\end{array}$ \\
p105 & F: GATGGGACGACACCTCTACACATA \\
& R: CCCAAGAGTCGTCCAGGTCA \\
p100 & F: CTGATGGCACAGGACGAGAA \\
& R: TGGGCTATCTGCTCAATGACAC \\
p65 & F: CGACGTATTGCTGTGCCTTC \\
& R: TTGAGATCTGCCCAGGTGGTA \\
IKK & F: TACGGTCCCAATGGCTGTTT \\
& R: GGTATGTGTGAATGGTGCCTGT \\
TNF- $\alpha$ & F: TGGCGTGTTCATCCGTTCTCTAC \\
& R: CTACTTCAGCGTCTCGTGTGTTTC \\
\hline
\end{tabular}


Table II. Counts of inflammatory cells in colonic mucosa $(n=40$, mean \pm SD)

\begin{tabular}{ccccc}
\hline Groups & Neutrophils & Eosinophils & Lymphocytes & Macrophages \\
\hline Normal & $5.8 \pm 3.9^{\mathrm{a}}$ & $4.0 \pm 2.2^{\mathrm{a}}$ & $41.5 \pm 17.2^{\mathrm{a}}$ & $5.4 \pm 3.5^{\mathrm{a}}$ \\
Model & $44.2 \pm 6.6$ & $15.4 \pm 4.2$ & $107.9 \pm 27.9$ & $17.8 \pm 6.8$ \\
GH & $18.1 \pm 5.0^{\mathrm{a}}$ & $12.8 \pm 5.0$ & $73.1 \pm 25.8^{\mathrm{a}}$ & $10.9 \pm 6.2^{\mathrm{a}}$ \\
HY & $17.7 \pm 5.1^{\mathrm{a}}$ & $13.2 \pm 4.3$ & $69.1 \pm 26.4^{\mathrm{a}}$ & $11.4 \pm 4.2^{\mathrm{a}}$ \\
\hline
\end{tabular}

Inflammatory cells from HE stained colonic tissue sections were counted in ten randomly selected high power fields (HPFs) at $400 \times$ magnification $\left({ }^{\mathrm{a}} P<0.05\right.$ relative to model group). 
Table III. Spearman correlation analysis between $\mathbf{N}$ and $\mathrm{M}$ groups (when signal pathway was activated)

\begin{tabular}{|c|c|c|c|c|}
\hline $\begin{array}{c}\text { Indicators in } \\
\text { NF-кB pathway }\end{array}$ & Neutrophils & Eosinophils & Lymphocytes & Macrophages \\
\hline \multicolumn{5}{|l|}{ Proteins } \\
\hline IKK & $0.702^{\mathrm{a}}$ & $0.720^{\mathrm{a}}$ & $0.693^{\mathrm{a}}$ & $0.719^{\mathrm{a}}$ \\
\hline $\mathrm{pIKK}$ & $0.913^{\mathrm{a}}$ & $0.841^{\mathrm{a}}$ & $0.838^{\mathrm{a}}$ & $0.725^{\mathrm{a}}$ \\
\hline p65 & 0.426 & 0.402 & 0.354 & 0.180 \\
\hline p-p65 & $0.961^{\mathrm{a}}$ & $0.952^{\mathrm{a}}$ & $0.962^{\mathrm{a}}$ & $0.890^{\mathrm{a}}$ \\
\hline $\mathrm{I} \kappa \mathrm{B} \alpha$ & $-0.942^{\mathrm{a}}$ & $-0.660^{\mathrm{a}}$ & $-0.960^{\mathrm{a}}$ & $-0.835^{\mathrm{a}}$ \\
\hline $\mathrm{p}-\mathrm{I \kappa} \mathrm{B} \alpha$ & $0.927^{\mathrm{a}}$ & $0.972^{\mathrm{a}}$ & $0.906^{\mathrm{a}}$ & $0.944^{\mathrm{a}}$ \\
\hline TNF- $\alpha$ & $0.988^{\mathrm{a}}$ & $0.904^{\mathrm{a}}$ & $0.910^{\mathrm{a}}$ & $0.885^{\mathrm{a}}$ \\
\hline nuclear p65 & $0.986^{\mathrm{a}}$ & $0.977^{\mathrm{a}}$ & $0.966^{\mathrm{a}}$ & $0.948^{\mathrm{a}}$ \\
\hline \multicolumn{5}{|l|}{ mRNAs } \\
\hline p105 & $0.980^{\mathrm{a}}$ & $0.940^{\mathrm{a}}$ & $0.975^{\mathrm{a}}$ & $0.938^{\mathrm{a}}$ \\
\hline p100 & $0.823^{\mathrm{a}}$ & $0.926^{\mathrm{a}}$ & $0.910^{\mathrm{a}}$ & $0.921^{\mathrm{a}}$ \\
\hline IKK & $0.890^{\mathrm{a}}$ & $0.975^{\mathrm{a}}$ & $0.921^{\mathrm{a}}$ & $0.923^{\mathrm{a}}$ \\
\hline p65 & $0.692^{\mathrm{a}}$ & $0.860^{\mathrm{a}}$ & $0.674^{\mathrm{a}}$ & $0.936^{\mathrm{a}}$ \\
\hline TNF- $\alpha$ & $0.864^{\mathrm{a}}$ & $0.920^{\mathrm{a}}$ & $0.890^{\mathrm{a}}$ & $0.929^{\mathrm{a}}$ \\
\hline
\end{tabular}

Statistical analyses were performed by the Spearman correlation analysis. ${ }^{\mathrm{a}} P<0.05$ was considered significant. 
Table IV. Spearman correlation analysis between $\mathbf{N}, \mathbf{M}$ and GH groups (when signal pathway was suppressed)

\begin{tabular}{|c|c|c|c|c|}
\hline $\begin{array}{c}\text { Indicators in NF- } \\
\text { кB pathway }\end{array}$ & Neutrophils & Eosinophils & Lymphocytes & Macrophages \\
\hline \multicolumn{5}{|l|}{ Proteins } \\
\hline IKK & 0.323 & $0.774^{\mathrm{a}}$ & 0.260 & 0.455 \\
\hline pIKK & $0.918^{\mathrm{a}}$ & $0.854^{\mathrm{a}}$ & $0.821^{\mathrm{a}}$ & $0.780^{\mathrm{a}}$ \\
\hline p65 & $0.590^{\mathrm{a}}$ & 0.180 & 0.422 & 0.191 \\
\hline p-p65 & $0.826^{\mathrm{a}}$ & $0.938^{\mathrm{a}}$ & $0.878^{\mathrm{a}}$ & $0.964^{\mathrm{a}}$ \\
\hline $\mathrm{I} \kappa \mathrm{B} \alpha$ & $-0.854^{\mathrm{a}}$ & $-0.660^{\mathrm{a}}$ & $-0.820^{\mathrm{a}}$ & $-0.721^{\mathrm{a}}$ \\
\hline $\mathrm{p}-\mathrm{I} \kappa \mathrm{B} \alpha$ & $0.860^{\mathrm{a}}$ & $0.850^{\mathrm{a}}$ & $0.821^{\mathrm{a}}$ & $0.905^{\mathrm{a}}$ \\
\hline TNF- $\alpha$ & $0.945^{\mathrm{a}}$ & $0.880^{\mathrm{a}}$ & $0.908^{a}$ & $0.877^{\mathrm{a}}$ \\
\hline nuclear p65 & $0.911^{\mathrm{a}}$ & $0.902^{\mathrm{a}}$ & $0.927^{\mathrm{a}}$ & $0.916^{\mathrm{a}}$ \\
\hline \multicolumn{5}{|l|}{ mRNAs } \\
\hline p105 & $0.926^{\mathrm{a}}$ & $0.689^{\mathrm{a}}$ & $0.962^{\mathrm{a}}$ & $0.826^{\mathrm{a}}$ \\
\hline p100 & $0.839^{\mathrm{a}}$ & $0.663^{\mathrm{a}}$ & $0.904^{\mathrm{a}}$ & $0.865^{\mathrm{a}}$ \\
\hline IKK & $0.933^{\mathrm{a}}$ & $0.695^{\mathrm{a}}$ & $0.903^{\mathrm{a}}$ & $0.870^{\mathrm{a}}$ \\
\hline p65 & $0.658^{\mathrm{a}}$ & $0.930^{\mathrm{a}}$ & $0.699^{\mathrm{a}}$ & $0.844^{\mathrm{a}}$ \\
\hline TNF- $\alpha$ & $0.860^{\mathrm{a}}$ & $0.670^{\mathrm{a}}$ & $0.890^{\mathrm{a}}$ & $0.860^{\mathrm{a}}$ \\
\hline
\end{tabular}

Statistical analyses were performed by the Spearman correlation analysis. ${ }^{\mathrm{a}} P<0.05$ was considered significant. 
Table V. Pearson correlation analysis between $\mathrm{N}, \mathrm{M}$ and HY groups (when signal pathway was suppressed)

\begin{tabular}{|c|c|c|c|c|}
\hline $\begin{array}{c}\text { Indicators in NF- } \\
\kappa B \text { pathway }\end{array}$ & Neutrophils & Eosinophils & Lymphocytes & Macrophages \\
\hline \multicolumn{5}{|l|}{ Proteins } \\
\hline IKK & 0.421 & $0.668^{\mathrm{a}}$ & 0.433 & $0.699^{\mathrm{a}}$ \\
\hline pIKK & $0.894^{\mathrm{a}}$ & $0.502^{\mathrm{a}}$ & $0.831^{\mathrm{a}}$ & $0.706^{\mathrm{a}}$ \\
\hline p65 & 0.149 & $0.560^{\mathrm{a}}$ & 0.091 & 0.124 \\
\hline p-p65 & $0.862^{\mathrm{a}}$ & $0.864^{\mathrm{a}}$ & $0.902^{\mathrm{a}}$ & $0.945^{\mathrm{a}}$ \\
\hline $\mathrm{I} \kappa \mathrm{B} \alpha$ & $-0.944^{\mathrm{a}}$ & $-0.660^{\mathrm{a}}$ & $-0.892^{\mathrm{a}}$ & $-0.761^{\mathrm{a}}$ \\
\hline $\mathrm{p}-\mathrm{I} \kappa \mathrm{B} \alpha$ & $0.894^{\mathrm{a}}$ & 0.352 & $0.882^{\mathrm{a}}$ & $0.862^{\mathrm{a}}$ \\
\hline TNF- $\alpha$ & $0.956^{\mathrm{a}}$ & 0.361 & $0.846^{\mathrm{a}}$ & $0.796^{\mathrm{a}}$ \\
\hline nuclear p65 & $0.905^{\mathrm{a}}$ & $0.830^{\mathrm{a}}$ & $0.927^{\mathrm{a}}$ & $0.929^{\mathrm{a}}$ \\
\hline \multicolumn{5}{|l|}{ mRNAs } \\
\hline p105 & $0.968^{\mathrm{a}}$ & $0.569^{\mathrm{a}}$ & $0.890^{\mathrm{a}}$ & $0.871^{\mathrm{a}}$ \\
\hline p100 & $0.825^{\mathrm{a}}$ & $0.496^{\mathrm{a}}$ & $0.915^{\mathrm{a}}$ & $0.857^{\mathrm{a}}$ \\
\hline IKK & $0.952^{\mathrm{a}}$ & $0.595^{\mathrm{a}}$ & $0.924^{\mathrm{a}}$ & $0.824^{\mathrm{a}}$ \\
\hline p65 & $0.551^{\mathrm{a}}$ & $0.935^{\mathrm{a}}$ & $0.635^{\mathrm{a}}$ & $0.735^{\mathrm{a}}$ \\
\hline TNF- $\alpha$ & $0.856^{\mathrm{a}}$ & 0.324 & $0.835^{\mathrm{a}}$ & $0.789^{\mathrm{a}}$ \\
\hline
\end{tabular}

Statistical analyses were performed by the Spearman correlation analysis. ${ }^{a} P<0.05$ was considered significant. 
Structure: GHWKVWL (GL-7)

Lot NO: P181121-CQ449011

Number: 0200047

Column: $250 * 4.6 \mathrm{~mm}$, Kromasil-C18-5um

Solvent A: $0.1 \%$ TFA in $100 \%$ acetonitrile

Solvent B: $0.1 \%$ TFA in $100 \%$ water

Gradient:

A B

\begin{tabular}{lcr}
$0.01 \min$ & $27 \%$ & $73 \%$ \\
$25 \min$ & $52 \%$ & $48 \%$ \\
$25.1 \min$ & $100 \%$ & $0 \%$ \\
$30 \min$ & \multicolumn{2}{c}{ Stop } \\
\hline
\end{tabular}

Flow rate: $1.0 \mathrm{ml} / \mathrm{min}$

Wavelength(nm): 220

Volume: 5ul

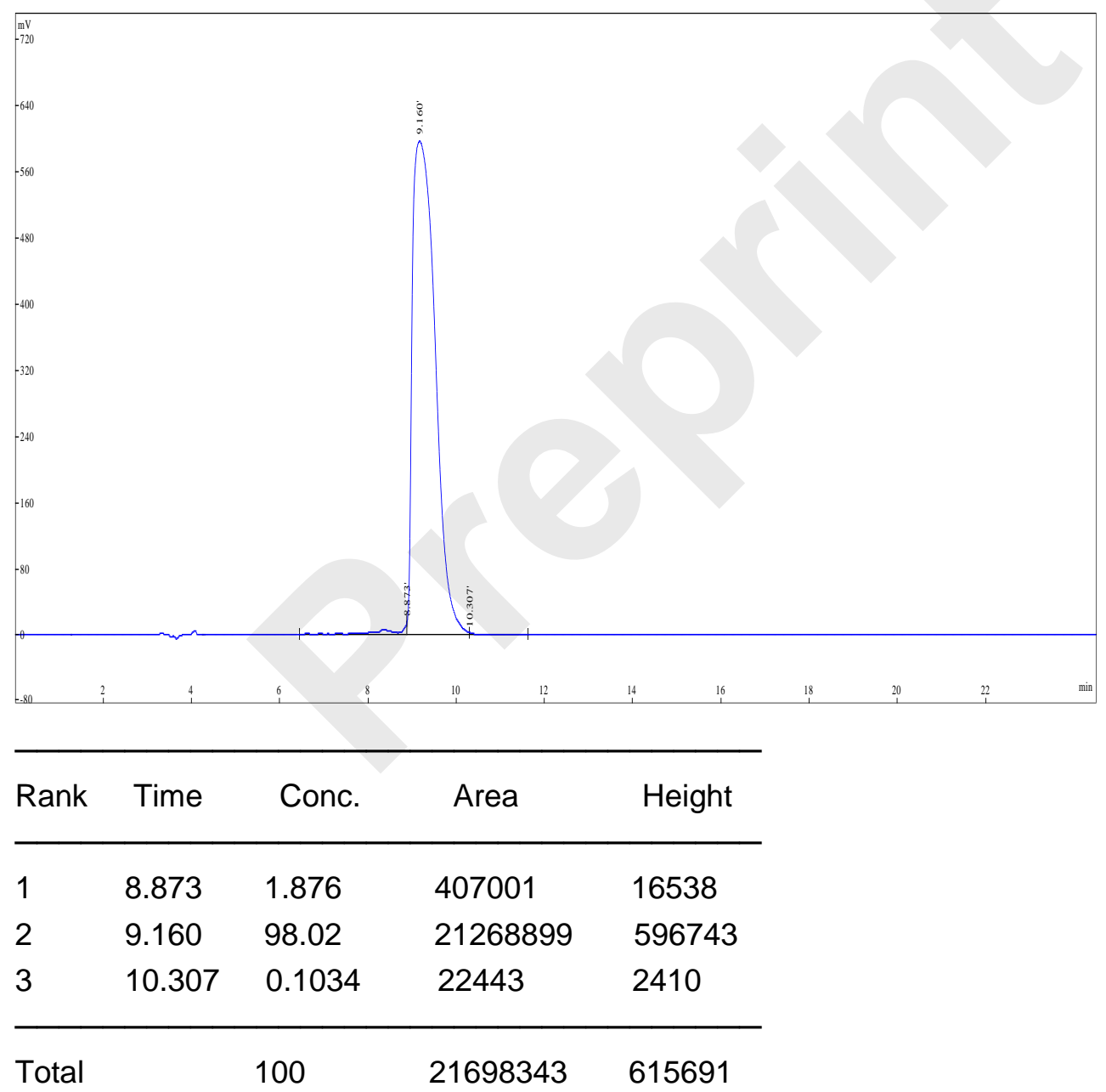


HPLC analysis report

Structure: HYIDFRW HW-7

Lot NO: P181121-CQ417038

Number: 0200049

Column: $250 * 4.6 \mathrm{~mm}$, Kromasil-C18-5um

Solvent A: 0.1\%TFA in 100\%water

Solvent B: $0.1 \%$ TFA in $100 \%$ acetonitrile

Gradient:

A B

$\begin{array}{ccr}0.1 \min & 75 \% & 25 \% \\ 25.0 \min & 50 \% & 50 \% \\ 25.1 \min & 0 \% & 100 \% \\ 30.0 \min & \text { stop } & \end{array}$

Flow rate: $1.0 \mathrm{ml} / \mathrm{min}$

Wavelength $(\mathrm{nm}): 220$

Volume: 10ul

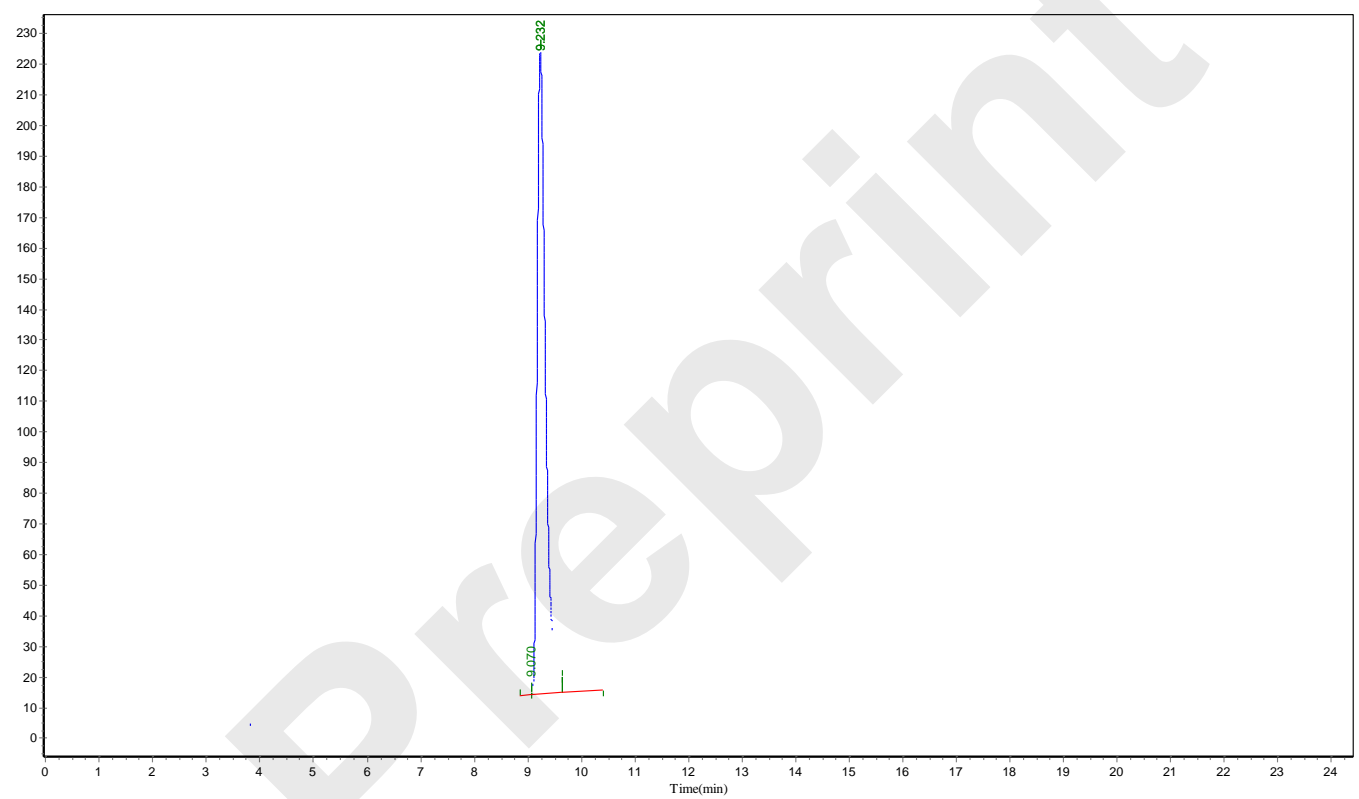

\begin{tabular}{lllll} 
Peak No. & \multicolumn{2}{c}{ Ret Time $\quad$ Height } & \multicolumn{1}{c}{ A rea } & Conc. \\
1 & 9.070 & 581.791 & 4171.102 & 0.1745 \\
2 & 9.232 & 210287.891 & 2305138.750 & 96.4298 \\
3 & 9.232 & 5899.023 & 81174.703 & 3.3957 \\
\hline Total & & & & 100.00
\end{tabular}



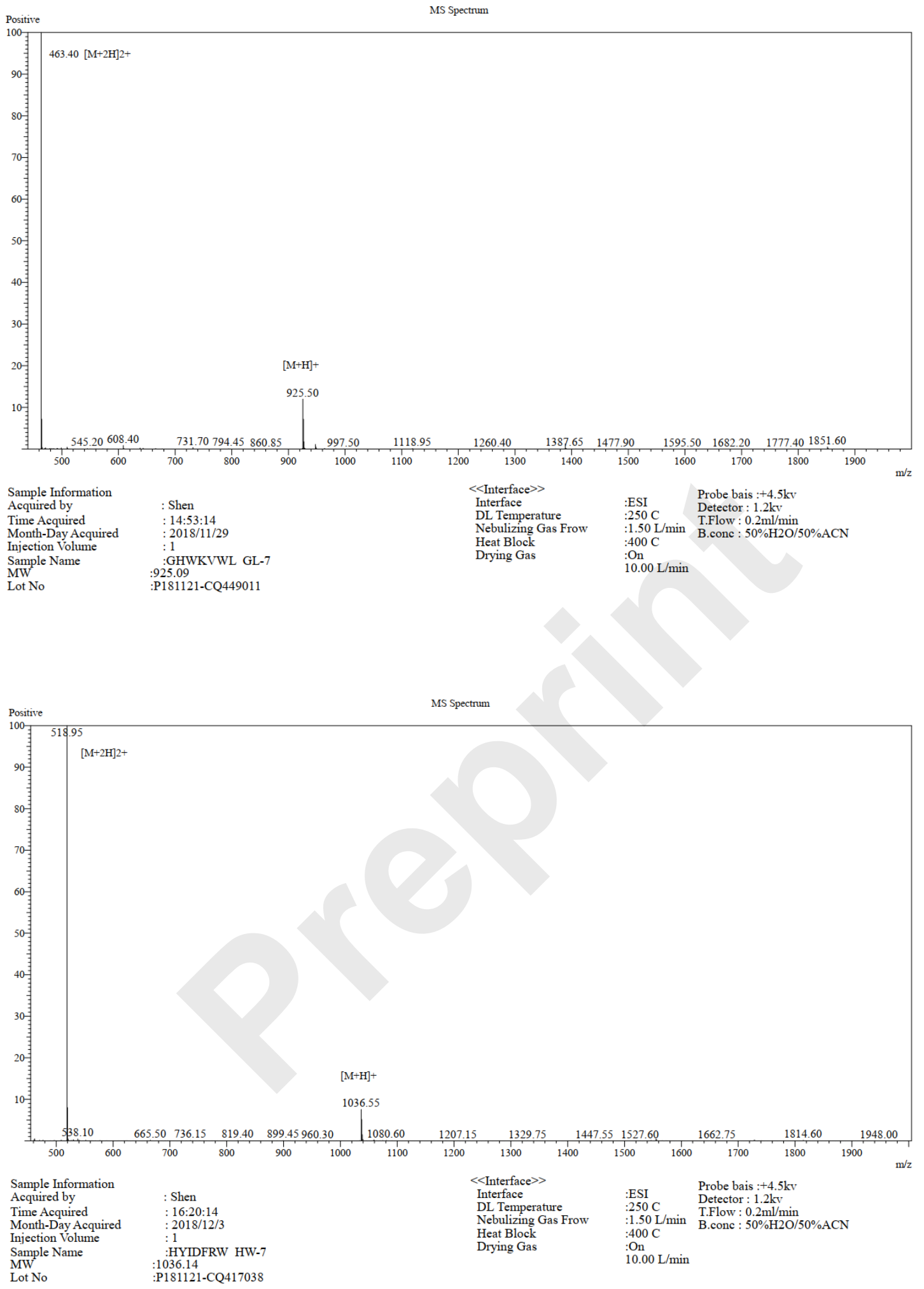
Table S1 Effects of GH peptide and HY peptide at different concentrations on CMDI and histological grading score $($ Mean \pm SD)

\begin{tabular}{ccc}
\hline Treatment & CMDI & Histological score \\
\hline Model & $5.60 \pm 0.75$ & $30.92 \pm 5.47$ \\
G1 $(25 \mathrm{mg} / \mathrm{kg})$ & $5.00 \pm 0.45$ & $18.25 \pm 4.92$ \\
G2 $(35 \mathrm{mg} / \mathrm{kg})$ & $4.80 \pm 0.49$ & $10.93 \pm 3.79^{*}$ \\
G3 $(45 \mathrm{mg} / \mathrm{kg})$ & $7.00 \pm 0.71$ & $27.56 \pm 6.47$ \\
H1 $(15 \mathrm{mg} / \mathrm{kg})$ & $3.80 \pm 1.24$ & $15.32 \pm 5.41^{*}$ \\
H2 $(25 \mathrm{mg} / \mathrm{kg})$ & $2.00 \pm 0.32^{*}$ & $7.33 \pm 1.45^{*}$ \\
H3 $(35 \mathrm{mg} / \mathrm{kg})$ & $4.80 \pm 0.74$ & $25.48 \pm 5.15$ \\
\hline
\end{tabular}

CMDI: Colon macroscopic damage index [1]

Histological score: Evaluated according to literature [2]

*: $P<0.05$ vs model group
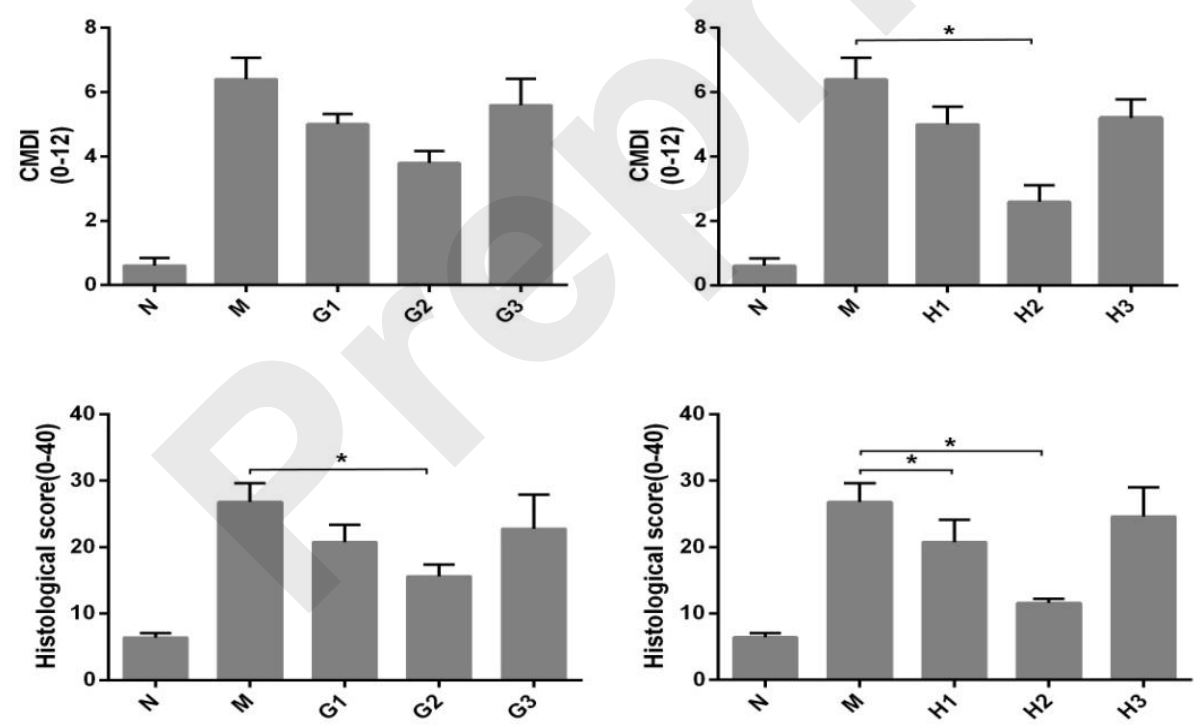

Reference:

1. Paiotti APR, Miszputen SJ, Oshima CTF, et al. Etanercept attenuates TNBSinduced experimental colitis: role of TNF- $\alpha$ expression[J]. J Mol Histol, 2011, 42(5):443-450.

2. Dieleman LA, Palmen MJ, Akol H, et al. Chronic experimental colitis induced by 
dextran sulphate sodium (DSS) is characterized by Th1 and Th2 cytokines[J]. Clin Exp Immunol, 1998, 114(3):385-391. 
Table S1

\begin{tabular}{|c|c|c|c|c|c|}
\hline Behaviour & $\begin{array}{l}\text { Locomotory } \\
\text { signs }\end{array}$ & Nervous signs & $\begin{array}{l}\text { Respiratory } \\
\text { signs }\end{array}$ & $\begin{array}{l}\text { Digestive } \\
\text { signs }\end{array}$ & Score \\
\hline $\begin{array}{l}\text { Active, } \\
\text { playful, } \\
\text { attentive }\end{array}$ & $\begin{array}{l}\text { No } \\
\text { locomotory } \\
\text { signs }\end{array}$ & Normal & Normal & $\begin{array}{l}\text { Clean } \\
\text { hind legs, } \\
\text { no } \\
\text { diarrhoea } \\
\text { observed }\end{array}$ & 0 \\
\hline $\begin{array}{l}\text { Sad, a bit } \\
\text { passive }\end{array}$ & $\begin{array}{l}\text { Swelling of } \\
\text { joint(s) } \\
\text { visible, but } \\
\text { none or only } \\
\text { mild } \\
\text { lameness. }\end{array}$ & $\begin{array}{l}\text { Tremor or } \\
\text { mild } \\
\text { incoordination. }\end{array}$ & $\begin{array}{l}\text { Mild } \\
\text { dyspnoea } \\
\text { and/or } \\
\text { coughing }\end{array}$ & $\begin{array}{l}\text { Dirty } \\
\text { anus or } \\
\text { pasty } \\
\text { diarrhoea } \\
\text { observed }\end{array}$ & 1 \\
\hline $\begin{array}{l}\text { Mild } \\
\text { depression, } \\
\text { but still } \\
\text { attentive }\end{array}$ & $\begin{array}{l}\text { Swelling of } \\
\text { joint(s) } \\
\text { visible } \\
\text { and/or } \\
\text { moderate } \\
\text { lameness. }\end{array}$ & $\begin{array}{l}\text { Moderate } \\
\text { nervous signs, } \\
\text { difficulties to } \\
\text { walk. }\end{array}$ & $\begin{array}{l}\text { Severe } \\
\text { dyspnoea } \\
\text { and/or } \\
\text { severe } \\
\text { coughing }\end{array}$ & $\begin{array}{l}\text { Dirty } \\
\text { hind legs } \\
\text { and/or } \\
\text { watery } \\
\text { diarrhoea } \\
\text { observed }\end{array}$ & 2 \\
\hline $\begin{array}{l}\text { Severe } \\
\text { depression, } \\
\text { passive, } \\
\text { prostrated. }\end{array}$ & $\begin{array}{l}\text { Severe } \\
\text { lameness, } \\
\text { unwilling to } \\
\text { move. }\end{array}$ & $\begin{array}{l}\text { Severe } \\
\text { nervous signs, } \\
\text { unable to } \\
\text { stand. }\end{array}$ & $\begin{array}{l}\text { Abdominal } \\
\text { breathing }\end{array}$ & $\begin{array}{l}\text { Dirty } \\
\text { hind legs } \\
\text { with } \\
\text { mucus } \\
\text { and/or } \\
\text { blood } \\
\text { and/or } \\
\text { severe } \\
\text { diarrhoea } \\
\text { with } \\
\text { mucus or } \\
\text { blood. }\end{array}$ & 3 \\
\hline
\end{tabular}

Animals with three scores of 2 in two different parameters or total score of $\geq 10$ were humanely euthanized immediately. 

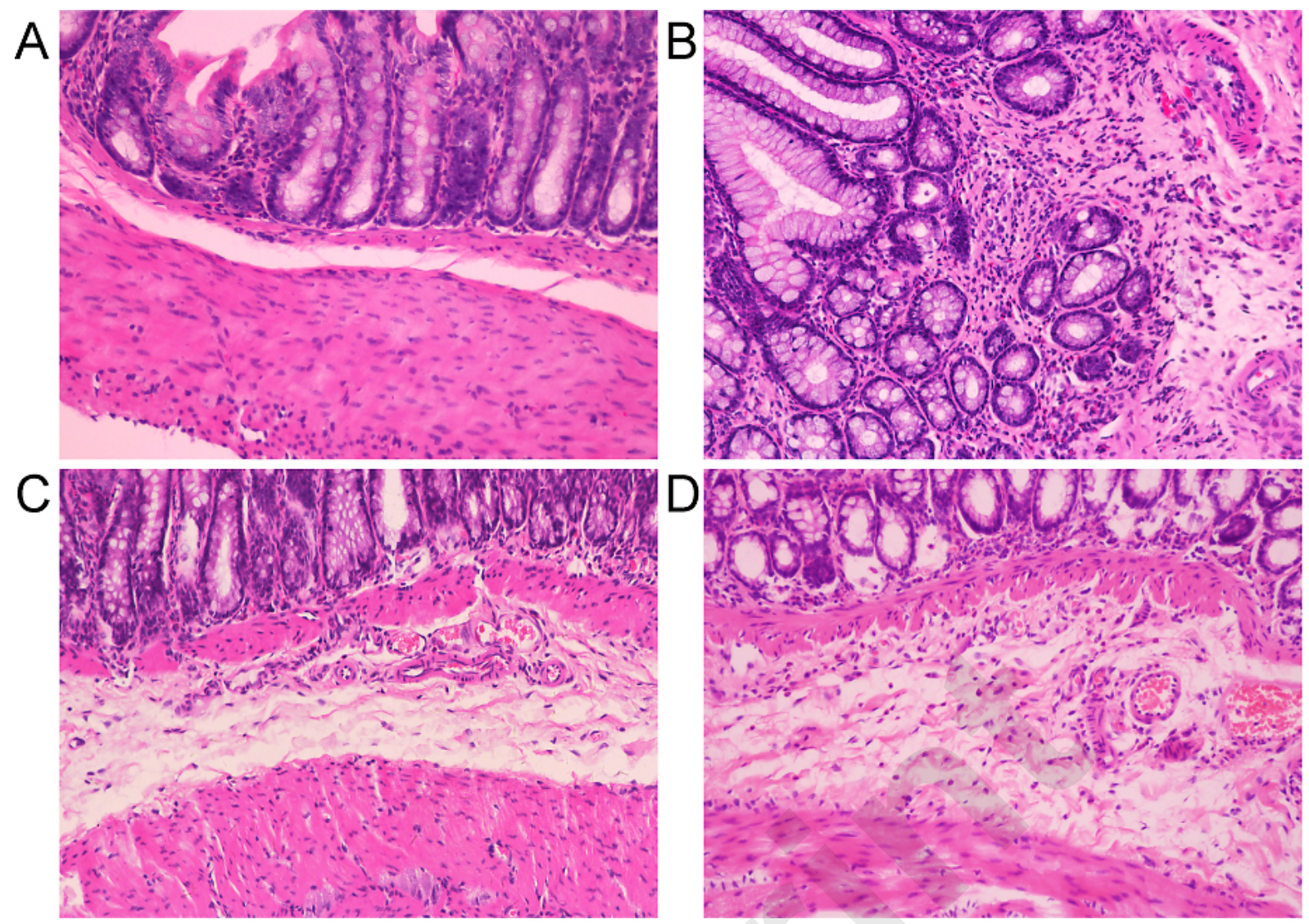

Figure 1. Histological changes in the colonic mucosa in each group (HE $\times 100)$.

(A) Normal control group. The structure of the colonic mucosa was intact. (B) Model group. TNBS enema resulted in ulceration, crypt distortion, and severe inflammation throughout the colonic mucosa and infiltration of large amounts of inflammatory cells. (C) GH peptide group. (D) HY peptide group. Inflammation in the GH and HY groups was mainly located in the submucosa, and infiltration of inflammatory cells was reduced significantly compared with that of the model group. 

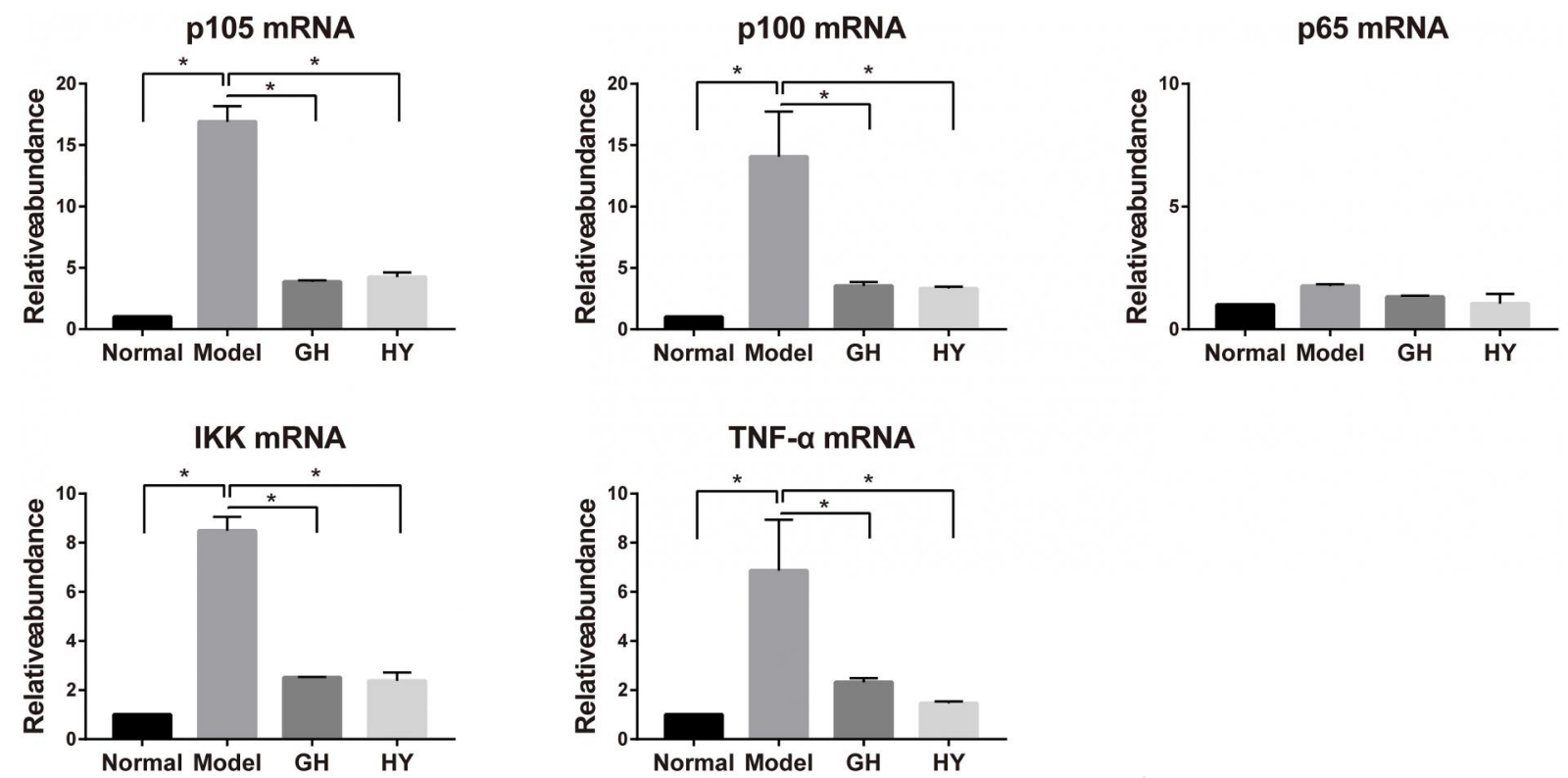

Figure 2. Expression of NF-kB-related genes in each group.

The results revealed that except for $\mathrm{p} 65, \mathrm{GH}$ and $\mathrm{HY}$ peptides significantly inhibited mRNA expression levels of p105 ( $77 \%$ and $74 \%$ inhibition for $\mathrm{GH}$ and $\mathrm{HY}$ peptides, respectively), p100 (74\% and 76\%), IKK (70\% and 72\%) and TNF- $\alpha(66 \%$ and $78 \%)\left({ }^{*} \mathrm{P}<0.01\right)$. 

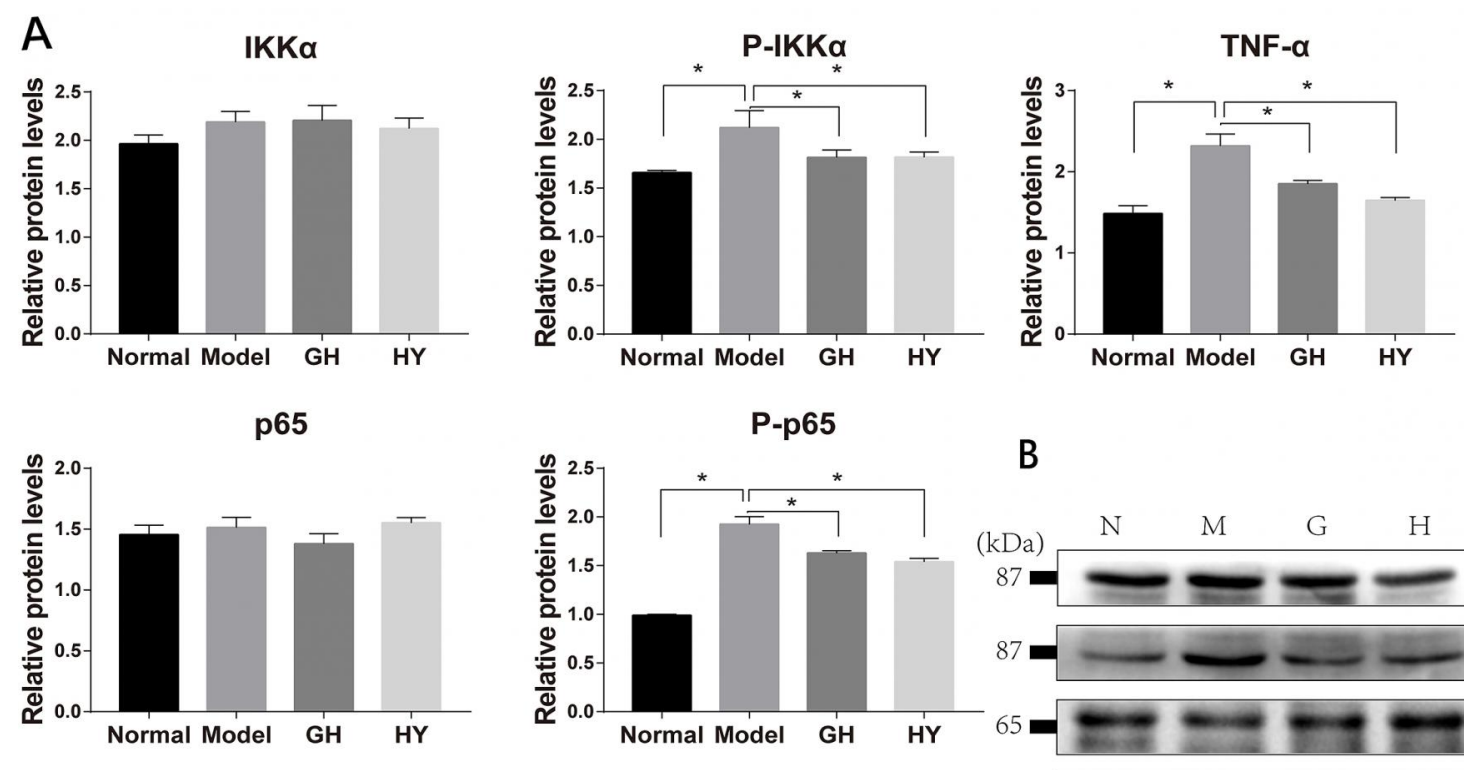

\section{B}
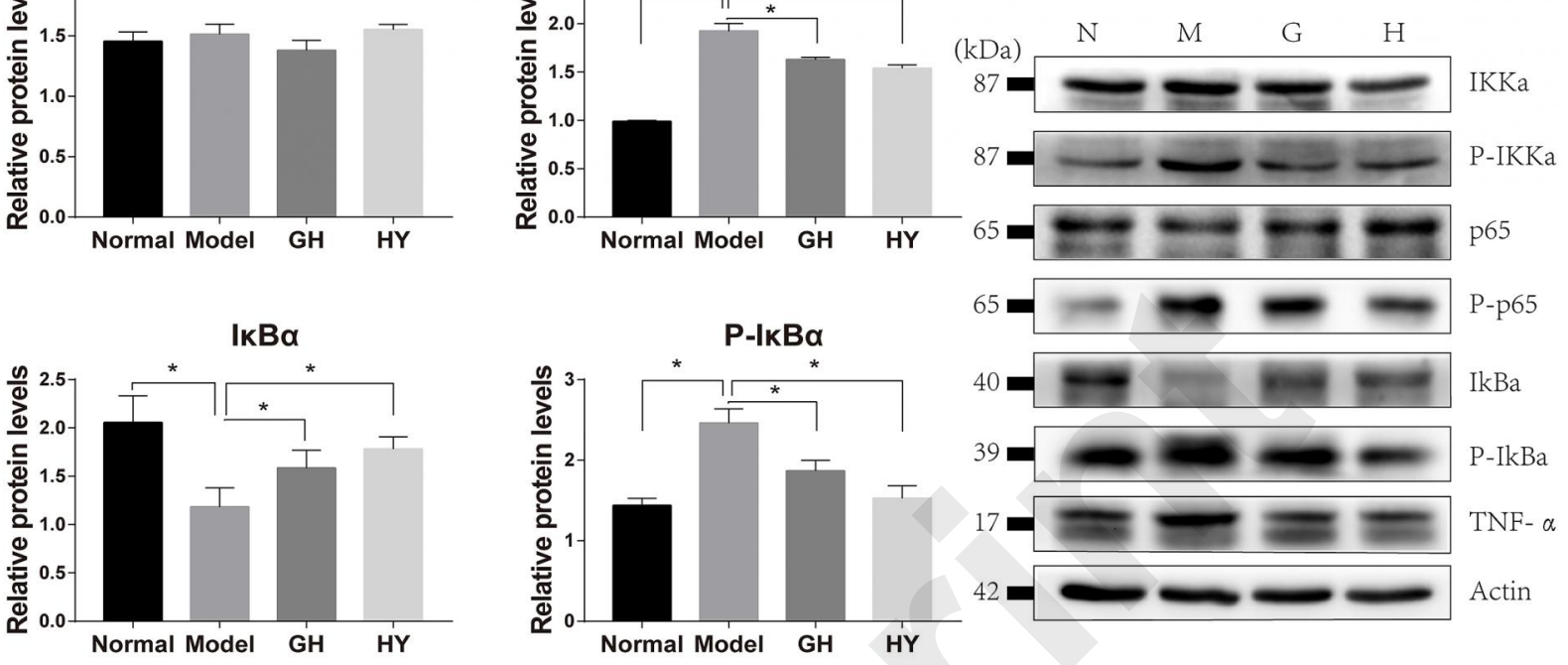

Figure 3. GH and HY peptides suppressed the NF-KB signaling pathway and phosphorylation of IKK, IKBa and p65.

$\beta$-actin was used as a loading control. The results showed that GH or HY peptide decreased the protein levels of $\mathrm{p}-\mathrm{IKK}, \mathrm{p}-\mathrm{p} 65, \mathrm{p}-\mathrm{IKB} \alpha$ and TNF- $\alpha$ compared with those of the model control $\left({ }^{*} P<0.05\right)$. 
A

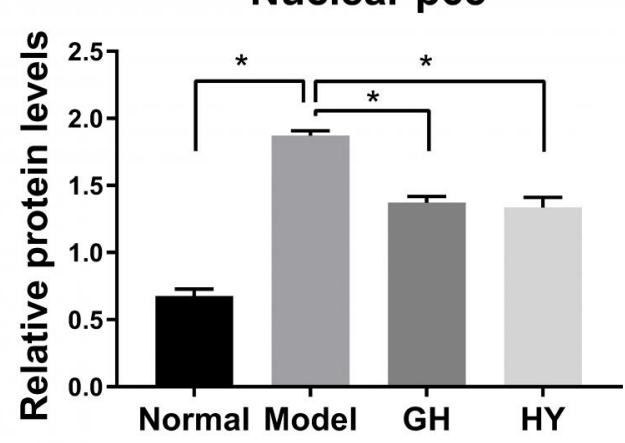

B

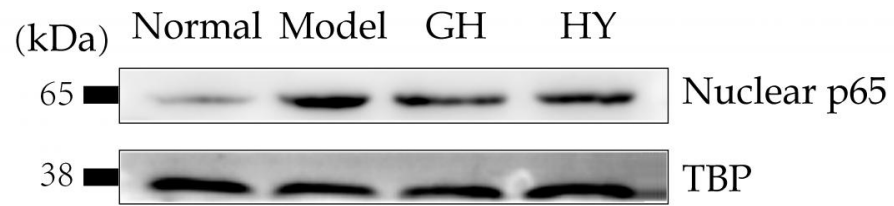

Figure 4. Effects of $\mathrm{GH}$ and $\mathrm{HY}$ peptides on the nuclear translocation of p65.

Nuclear protein was extracted and analyzed by western blotting for p65 expression. TBP was used as a loading control (lower panel). Quantification by gray value showed that the reduction in p65 was up to $32 \%$ and $33 \%$ in the $\mathrm{GH}$ and $\mathrm{HY}$ peptide groups, respectively ( ${ }^{*} \mathrm{P}$ $<0.05)$. 


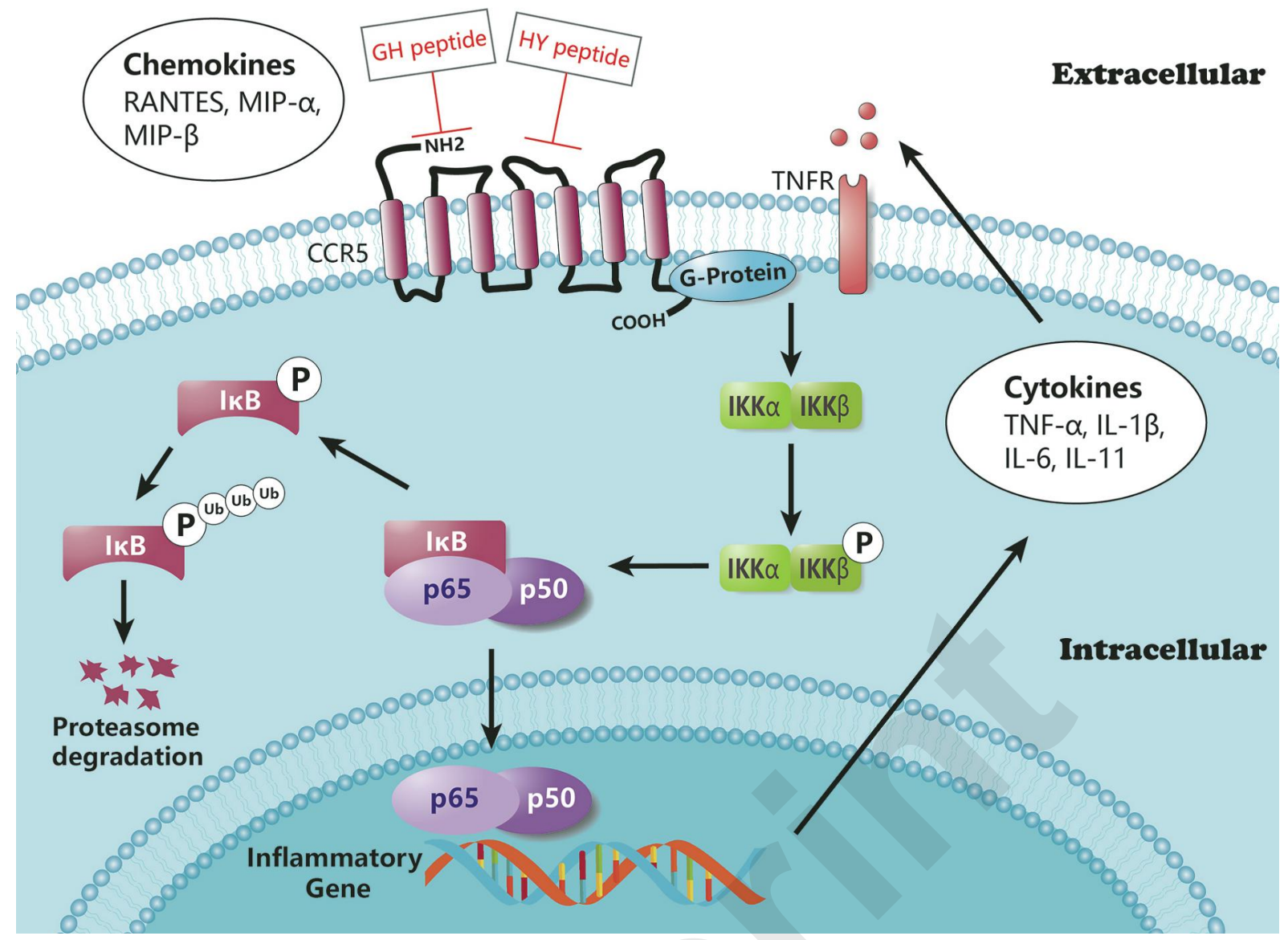

Figure 5. Effect of CCR5 binding peptides on the NF-kB pathway 

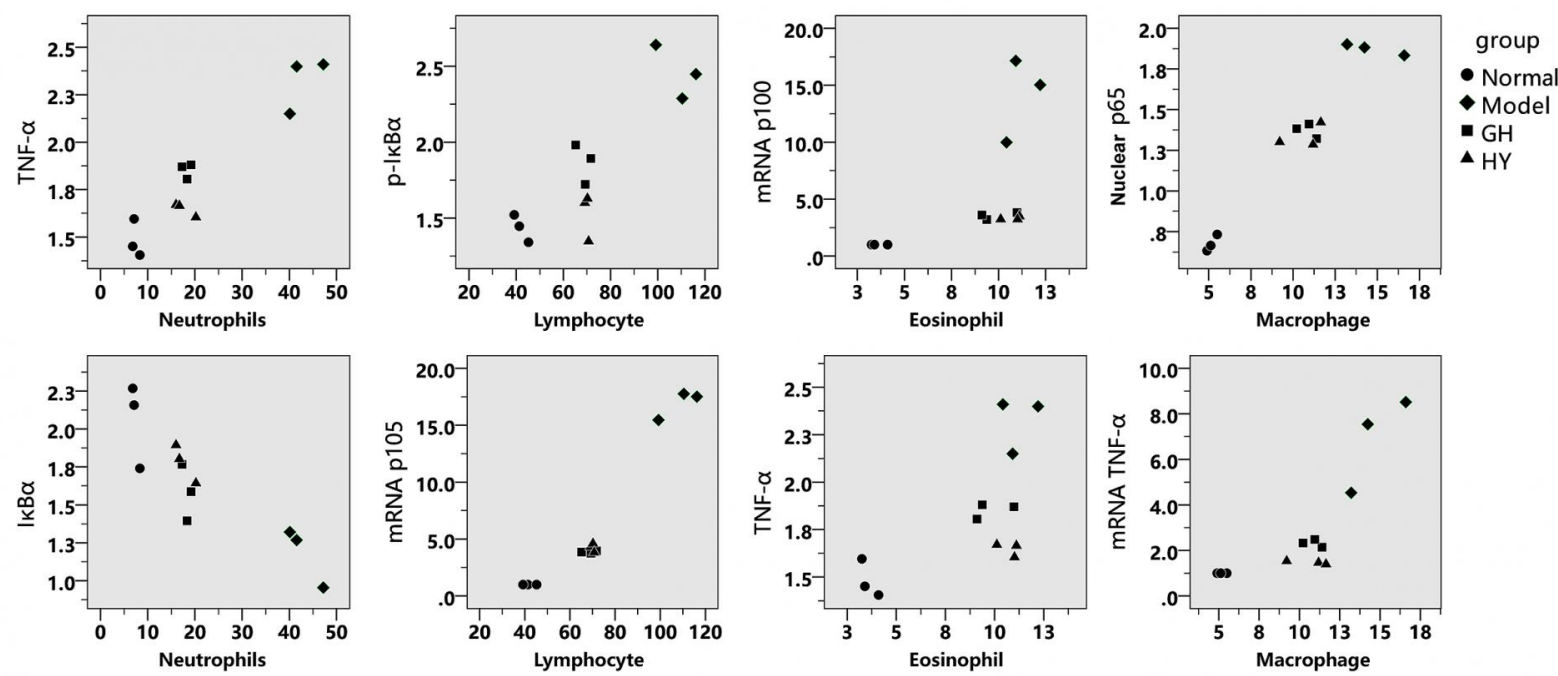

Figure S1. Parts of the scatter plot results 